\title{
Diet Compliance, Blood Glucose Levels, and Hospitalization Duration of Type II Diabetes Mellitus Patients with Hypertension Complications in the Pancaran Kasih General Hospital, Manado
}

Rivolta G. M. Walalangi ${ }^{1 *}$ (D), Nonce N. Legi ${ }^{1}$, Olivia Ondang ${ }^{1}$, Yohanis A. Tomastola ${ }^{1}$, Vera T. Harikedua ${ }^{1}$, Ellen Pesak ${ }^{2}$, Irza N. Ranti ${ }^{1}$, Ana B. Montol ${ }^{1}$, Olga L. Paruntu ${ }^{1}$, Daniel Robert ${ }^{1}$, Jufri Sineke ${ }^{1}$, Phembriah S. Kereh ${ }^{1}$, Olfie Sahelangi ${ }^{1}$ (iD

${ }^{1}$ Department of Nutrition, Politeknik Kesehatan Kementerian Kesehatan Manado, Manado, Indonesia; ${ }^{2}$ Department of Nursing, Politeknik Kesehatan Kementerian Kesehatan Manado, Manado, Indonesia

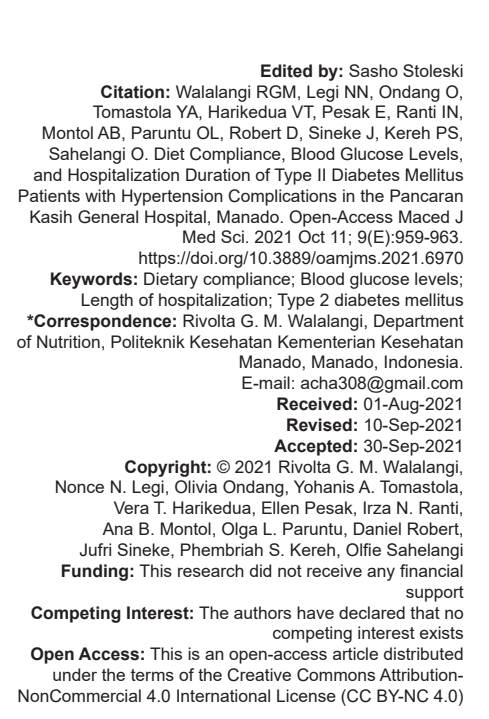

\section{Abstract}

BACKGROUD: Diabetes mellitus is an assembly of symptoms that arise in a person caused by increased blood sugar levels due to insulin deficiency, both absolute and relative. The highest prevalence in North Sulawesi is in Tomohon City (4.8\%) then Manado City (3.2\%)

AIM: This study aimed to determine the correlation between dietary compliance with blood glucose levels and duration of hospitalization of type 2 diabetes mellitus (T2DM) patients with hypertension complications in the Pancaran Kasih General Hospital, Manado.

METHOD: This research was observational with a cross-sectional design. The population in this study were al patients with type 2 diabetes who were hospitalized and 34 people involved as a sample through purposive sampling technique.

RESULTS: The results showed that $88.2 \%$ of respondents with not normal blood glucose did not adhere to the diet. Fisher's test obtained $p=0.011(p<0.05)$, indicated a significant correlation between dietary compliance with blood glucose levels. About $82.4 \%$ of patients did not adhere to the diet with a long day of hospitalization and $p=0.027$ $(p<0.05)$. It indicated a significant correlation between dietary compliance and length of stay.

CONCLUSION: This study concluded a correlation between dietary compliance with blood glucose levels and dietary compliance and length of stay for T2DM patients with hypertension complications.

\section{Introduction}

According to the World Health Organization (WHO), diabetes mellitus is a chronic disease that occurs when the pancreas does not produce enough insulin or when the body does not use the insulin it produces effectively [1]. Meanwhile, according to the American Diabetes Association (ADA), diabetes is a group of diseases characterized by high glucose levels due to insulin production, how insulin works, or both [2]. Diabetes mellitus according to the International Diabetes Federation (IDF), there are 415 million people worldwide who suffer from diabetes mellitus, of which one in 11 people already has diabetes and is expected to increase in 2040 to 642 million people where one in 10 people will have diabetes [3].

In Indonesia, diabetes mellitus reaches 1.5\%, with the highest prevalence in DI Yogyakarta at 2.6\% and the lowest is in Lampung at $0.7 \%$. Specifically, in North Sulawesi Province, the highest prevalence of diabetes mellitus is in Tomohon City at $4.8 \%$ and followed by Manado City at $3.2 \%$ [4]. Diet is one of the main treatments in the management of diabetes mellitus. The main purpose of this diabetes mellitus diet is to improve general health, maintain blood glucose levels close to normal, and meet nutritional needs in achieving and maintaining nutritional status [5].

Disobedience to diet can also cause complications. According to Risnasari (2014) [6], there is an association between the level of dietary adherence of diabetes mellitus patients with the emergence of complications. In addition, the length of hospitalization is influenced by nutritional status, where nutrition can play a role in the healing process [7].

This study aimed to determine the correlation between dietary compliance with blood glucose levels and duration of hospitalization of type 2 diabetes mellitus (T2DM) patients with hypertension complications in the Pancaran Kasih General Hospital, Manado. 


\section{Methods}

This research was observational with a crosssectional study design. This research was conducted at the General Hospital of GMIM Pancaran Kasih, Manado. The variables in this study consisted of the independent variable (dietary compliance) and the dependent variable (blood glucose levels and length of hospitalization). The population in this study were patients with T2DM who were hospitalized. Through purposive sampling, the samples were 34 respondents, taken based on the inclusion criteria (adult patients aged 19 years, DM with complications of hypertension, good awareness, had undergone at least 1 day of hospitalization, could communicate well, and were willing to be respondents).

The instruments used were the respondent's identity form, the estimated food waste form to measure dietary compliance and medical records. Data were collected through interviews with primary data collected, including respondent's identity, dietary compliance, and length of hospitalization (counting the initial days of admission until the end of the study). Secondary data were the general description of the hospital obtained from the hospital report book, fasting blood glucose (FBG) levels were obtained from medical records, and the standard portion of the hospital was obtained from data at the nutrition installation.

The category of dietary compliance is obey if the remaining food is $<20 \%$. Disobedience if the remaining food is above $20 \%$. Kategori status gizi (body mass index [BMI]) dibagi menjadi 3 yaitu normal (18.5-25), overweight (25-27), and obesitas (>27). The criteria for high blood pressure used the JNC7 criteria [8]: Systolic blood pressure (SBP) $\geq 140 \mathrm{mmHg}$ or diastolic blood pressure $\geq 90 \mathrm{mmHg}$. The criteria for high blood sugar levels used the WHO criteria, FBG $\geq 126 \mathrm{mg} / \mathrm{dl}$ [9]. The length of hospitalization category is short if $<5$ days, long if more than 5 days

Statistically, data were analyzed by the Fisher's exact test with $\alpha=0.05$ and using SPSS program.

\section{Results}

\section{Characteristics respondent}

Table 1 shows that of the 34 subjects, $61.8 \%$ were female and $38.2 \%$ were male. The number of respondents based on age was the highest in the range of $61-67$ years old $(29.4 \%)$ and the least in the age range of $75-81$ years old $(2.9 \%)$. Table 1 shows that the nutritional status of respondent is $67.6 \%$ (normal), $17.6 \%$ (overweight), and $14.7 \%$ (obese). Based on education level, most respondents have a high school education level of $32.4 \%$ and the least $2.9 \%$ of an associate degree (D-III) graduates. Distribution by occupation shows that the most significant percentage was household workers at $44.1 \%$, and the lowest percentage was traders and fishermen at $2.9 \%$ each.

Table 1: Characteristics of respondent

\begin{tabular}{llll}
\hline Variables & Categories & $\mathrm{n}$ & $\%$ \\
\hline Gender & Males & 13 & 38.2 \\
& Females & 21 & 61.8 \\
Age (y.o) & Total & 34 & 100 \\
& $40-46$ & 7 & 20.6 \\
& $47-53$ & 8 & 23.5 \\
& $54-60$ & 6 & 17.6 \\
& $61-67$ & 10 & 29.4 \\
& $68-74$ & 2 & 5.9 \\
\multirow{5}{*}{ Nutritional status (BMI) } & $75-81$ & 1 & 2.9 \\
& Total & 34 & 100 \\
& Normal & 23 & 67.6 \\
Education & Overweight & 6 & 17.6 \\
& Obesitas & 5 & 14.7 \\
& Total & 34 & 100 \\
& Primary school & 8 & 23.5 \\
& Junior high school & 10 & 29.4 \\
& Senior high school & 11 & 32.4 \\
Job & Associate degree (D-III) & 1 & 2.9 \\
& Bachelor degree & 4 & 11.8 \\
& Total & 34 & 100 \\
& Civil servants & 3 & 8.8 \\
& Private & 6 & 17.6 \\
& Housewife & 15 & 44.1 \\
& Trader & 1 & 2.9 \\
& Farmer & 2 & 5.9 \\
& Pensionary & 3 & 8.8 \\
& Fisherman & 1 & 2.9 \\
& Teacher & 3 & 8.8 \\
& Total & 34 & 100 \\
\hline
\end{tabular}

\section{Research variable}

Table 2 shows that all respondents had SBP $140 \mathrm{mmHg}$ and diastolic $90 \mathrm{mmHg}$, about 34 respondents or $100 \%$, classified as hypertension. Most patients with T2DM did not comply with 32 respondents or $94.1 \%$, while 2 respondents (5.9\%) classified complied. FBG levels in T2DM patients mainly were not normal, about 30 respondents $(88.2 \%)$, while normal values were 4 respondents $(11.8 \%)$. Most patients with T2DM had long hospitalized days of 28 respondents $(82.6 \%)$, while the category of short hospitalization was $17.6 \%$ (six respondents).

Table 2: Research variable

\begin{tabular}{lll}
\hline Variable & $\mathrm{n}$ & $\%$ \\
\hline Blood pressure & & \\
$\quad$ Hypertension & 34 & 100 \\
$\quad$ Not hypertension & 0 & 0 \\
$\begin{array}{l}\text { Diet compliance } \\
\text { Yes }\end{array}$ & 2 & 5.9 \\
$\quad$ No & 32 & 94.1 \\
Fasting blood glucose & & \\
$\quad$ Normal & 4 & 11.8 \\
$\quad$ Not normal & 30 & 88.2 \\
Length of hospitalization & & 17.6 \\
$\quad$ Short & 6 & 82.4 \\
Long & 28 & 100 \\
$\quad$ Total & 34 & \\
\hline
\end{tabular}

\section{levels \\ Dietary compliance with blood glucose}

Table 3 shows that out of 34 respondents, $82 \%$ of respondents did not comply with the diet given 
with abnormal blood glucose levels, while $5.9 \%$ of respondents had normal blood glucose levels.

Table 3: Relationship of dietary compliance with blood glucose levels

\begin{tabular}{|c|c|c|c|c|c|c|c|}
\hline \multirow[t]{3}{*}{ Compliance to diet } & \multicolumn{4}{|c|}{ Fasting blood glucose } & \multirow{2}{*}{\multicolumn{2}{|c|}{ Total }} & \multirow[t]{3}{*}{$p$-value* } \\
\hline & \multicolumn{2}{|c|}{ Normal } & \multicolumn{2}{|c|}{ Not normal } & & & \\
\hline & $\mathrm{n}$ & $\%$ & $\mathrm{n}$ & $\%$ & $\mathrm{n}$ & $\%$ & \\
\hline Yes & 2 & 5.9 & 0 & 0 & 2 & 5.9 & 0.011 \\
\hline No & 2 & 5.9 & 30 & 88.2 & 32 & 94.1 & \\
\hline Total & 4 & 11.8 & 30 & 88.2 & 34 & 100 & \\
\hline
\end{tabular}

\section{Dietary compliance with length of hospitalization}

Table 4 shows 34 respondents with dietary compliance in the non-comply category and $82.4 \%$ tend to have prolonged hospital days.

Table 4: Correlation of dietary compliance with length of hospitalization

\begin{tabular}{|c|c|c|c|c|c|c|c|}
\hline \multirow[t]{3}{*}{ Compliance to diet } & \multicolumn{4}{|c|}{ Length of hospitalization } & \multirow{2}{*}{\multicolumn{2}{|c|}{ Total }} & \multirow[t]{3}{*}{$p$-value ${ }^{*}$} \\
\hline & \multicolumn{2}{|c|}{ Short } & \multicolumn{2}{|c|}{ Long } & & & \\
\hline & $\mathrm{n}$ & $\%$ & $\mathrm{n}$ & $\%$ & $\mathrm{n}$ & $\%$ & \\
\hline Yes & 2 & 5.9 & 0 & 0 & 2 & 5.9 & 0.027 \\
\hline No & 4 & 11.8 & 28 & 82.4 & 32 & 94.1 & \\
\hline Total & 6 & 17.6 & 28 & 82.4 & 34 & 100 & \\
\hline
\end{tabular}

\section{Discussion}

Based on the characteristics, there were 21 females (61.8\%) and 13 males (38.2\%) with T2DM. Fathurohman et al. (2016) revealed that female respondents tend to be risky toward DM than male respondents [10]. The female sex tends to be more at risk of developing diabetes mellitus related to a large BMI and menstrual cycle syndrome and during menopause which results in easy accumulation of fat which results in inhibition of glucose transport into cells [11]. Other research shows that respondents with diabetes are mostly middle age adults with an average age of 53 years. Most of them were female as many as 60 people $(69.8 \%)$ with most of them having suffered $>5$ years with an average length of suffering 5 years. From the results of the study, there was a relationship between age $(p=0.001)$, gender $(p=0.043)$, and length of time suffering from diabetes $(p=0.001)$ with the incidence of diabetic peripheral neuropathy [12].

Besides, respondents who are obedient to the DM diet have short hospitalization too. It is associated with an increased risk of diabetes because it can elevate insulin resistance and pancreatic beta-cell dysfunction [13]. Changes in body composition and hormones that occur during menopause can also affect the risk of diabetes [14]. Respondents in this study are $>40$ years old, who experience diabetes mellitus over 40 years. This is supported by the results of research conducted by Kurniawaty et al. (2016) [15].
There is a correlation between age and the incidence of T2DM. According to Smeltzer et al. (2010), age is one of the risk factors for T2DM disease, where this disease most often occurs in patients over 30 years of age [16]. The incidence of this disease increases with age, where the number of productive cells decreases with age [17].

The nutritional status of most respondents is in the normal category followed by overweight and obesity. Besides being caused by genetic factors, obesity can also cause diabetes. However, not all obese people can develop diabetes. Individuals who already have heredity diabetes plus an obese body condition are more likely to develop diabetes [18]. Glucose intolerance is also associated with obesity. In the elderly, there has been a decrease in insulin secretion and insulin resistance [19].

The majority of respondents in this study have high educational background. In line with Worang et al. (2013), most T2DM patients had the last education, namely, high school (57.1\%) [20]. The level of education can affect a person's acceptance of information. Patients with low education can make their level of knowledge less so that it will impact lifestyle, uncontrolled eating patterns, inappropriate food choices, and vice versa [21].

All respondents have blood pressure above normal which refers to hypertension. According to Trisnawati (2013) [11], people with hypertension are at greater risk of suffering from diabetes. Hypertension can appear as a complication of diabetes mellitus. Insulin can cause an increase in sodium retention in the kidneys, activity of the sympathetic nervous system, and potassium concentration in cells which causes an increase in vascular resistance so that it can affect an increase in blood pressure [22].

This study indicated many patients with T2DM who have not fully adhered to the given diet. This occurred because the respondent's condition is weak, resulting in reduced appetite. In terms of taste, it can also affect the respondent not spending the DM diet given by the hospital. This study is in line with Risnasari (2013) [11]; $56 \%$ of DM patients with a level of patient compliance do not comply with the recommended diet. Dietary compliance is one of the keys to success in the management of DM. This is because meal planning is one of the four main pillars in managing DM.

Diet is determined starting from the patient's condition, DM types, and the overall treatment program. Nutritional therapy is a significant component of success in the management of DM. Patient adherence to nutrition and meal planning principles is one of the obstacles in patients with diabetes mellitus. Many patients feel tormented concerning the amount and type of food recommended [16].

This study found that the number of respondents who had abnormal blood glucose levels 
was more than normal blood glucose. This is because the treated patients prefer to consume food from outside the hospital with the amount and type of food that is not following the DM diet. This is in line with the results of Dini et al. (2018) shows that $100 \%$ of respondents with type 2 diabetes have blood glucose levels $>126 \mathrm{mg} / \mathrm{dL}$ and include uncontrolled sugar levels [23].

Based on the results of this study, it shows that most of the respondents had a length of hospitalization of 5 days. It was calculated from the time the patient entered the hospital until the patient went home. This length of hospitalization occurs due to the condition of the body that is still weak and the condition of the disease and its complications. Complications of diabetes mellitus can be in the form of acute diseases such as hypoglycemia and chronic diseases such as kidney failure, heart and blood vessel disease, visual disturbances, foot ulcers and gangrene, and impotence. According to Lubis et al. (2018) [24], 54\% of T2DM patients have a length of stay 5 days. This is similar to the study conducted by Kasim et al. (2016) [7], which shows that $76.7 \%$ of patients with a length of stay $>6$ days are due to poor nutritional status or illness.

The Fisher's exact test results showed a significant relationship between dietary compliance with blood glucose levels where $p=0.011(p<0.05)$ (Table 3 ). The results of checking blood glucose levels were strongly influenced by dietary compliance of people with diabetes mellitus, where non-compliance had an impact, namely, the risk of decreasing health status leading to complications [25]. DM patient compliance in carrying out a diet is one of the essential matters in controlling DM [26]. Patients must adjust their diet according to the principles of the DM diet suggested by health workers since they can keep their blood sugar under control by adjusting the patient's diet [27]. Many DM patients experience failure in treatment, which might be caused by various factors, not complying with the proper diet. Complications from DM that can arise due to non-compliant patients carrying out the therapy program are dietary regulation, exercising, and drug usage [26]. Other research shows that the level of education has an important role in diet compliance where patients are required to understand 3J "Types, Amounts and Schedules" so that the lower level of education causes lower diet compliance [28]. Disobedience to diets causes sufferers to consume irregular foods which cause a pile of glucose and blood so that hyperglycemia occurs [28].

The Fisher's exact test results showed a significant relationship between dietary compliance with the number of days of hospitalization, $p=0.027(p<0.05)$ (Table 4). People with diabetes can be at risk for complications such as retinopathy, neuropathy, and nephropathy [29]. Complications of diabetes mellitus can affect life expectancy and patient motivation [30]. Psychological conditions also impact the length of hospitalization so that patients are required to be obedient in undergoing treatment. The results of the study state that non-compliance causes the patient's health status to deteriorate so that the risk is higher for hospitalization and can even be at risk of death [31]. Suppose the patient adheres to the diet given. In that case, it can speed up the healing process and shorten the day of hospitalization. The results of this study are not in line with other studies, namely there is no significant relationship between dietary compliance and length of stay for T2DM patients treated in the Inpatient Room at Pertamina Hospital Balikpapan in 2012 with $p=0.568$ [32]. The success of dietary management requires that the health professionals should have an orientation about the cultural beliefs, thoughts, family, and communal networks of the patients. As diabetes is a disease which continues for the lifetime, proper therapy methods with special emphasis on diet should be given by the healthcare providers in a way to control the disease, reduce the symptoms, and prevent the appearance of the complications [33].

\section{Conclusion}

Dietary compliance of patients with T2DM with hypertension in the General Hospital of Pancaran Kasih, Manado, was not complied (94.1\%) and complied (5.9\%). Most of them had not normal FBG $(88.2 \%)$ and long hospitalization (82.4\%). There was a significant correlation between dietary compliance toward blood glucose levels and length of hospitalization in patients with T2DM complications of hypertension in the Pancaran Kasih General Hospital, Manado. Patients with T2DM are suggested to obey the diet to control blood glucose levels and do not trigger other complications that weaken the body that affects the length of hospitalization. The patient's family needs to support and motivation to the patient in carrying out dietary recommendations. The Pancaran Kasih General Hospital, Manado, is suggested for special education and nutrition consultation for diabetes mellitus patients and their families related to the disease and DM management. It also includes educational media, such as leaflets, to install posters/billboards in the hospital environment. It is expected that it can be input and data for further researchers related to DM patients.

\section{References}

1. World Health Organization. Diabetes. Geneva: World Health Organization; 2021. Available from: https://www.who.int/ news-room/fact-sheets/detail/diabetes [Last accessed on 2021 Aug 01].

2. American Diabetes Association. Diagnosis and classification of diabetes mellitus. Diabetes Care. 2011;34 Suppl 1:S62-9. 
https://doi.org/10.2337/dc11-S062

\section{PMid:21193628}

3. Ogurtsova K, da Rocha Fernandes JD, Huang Y, Linnenkamp U, Guariguata L, Cho NH, et al. IDF diabetes atlas: Global estimates for the prevalence of diabetes for 2015 and 2040. Diabetes Res Clin Pract. 2017;128:40-50. https://doi.org/10.1016/j. diabres.2017.03.024

PMid:28437734

4. Kemenkes RI. Riset Kesehatan Dasar (RISKESDAS). Indonesia: Balitbang Kemenkes RI; 2013.

5. Gray A, Threlkeld RJ. Nutritional recommendations for individuals with diabetes. In: Feingold KR, Anawalt B, Boyce A, Chrousos G, de Herder WW, Dhatariya $\mathrm{K}$, et al., editors. Endotext. South Dartmouth, MA: MDText Inc.; 2000.

6. Risnasari N. Relation the degre of obedience diet of the patient of diabetes mellitus and the appearance of complication in puskesmas pesantren II town of Kediri. Efektor. 2014;25(1):15-9.

7. Kasim DA, Harikedua VT, Paruntu OL. Food Intake, nutritional status and length of hospitalization for internal medicine patients at manado adventist hospital. J GIZIDO. 2016;8(2):22-34.

8. Unger T, Borghi C, Charchar F, Khan NA, Poulter NR, Prabhakaran D, et al. 2020 international society of hypertension global hypertension practice guidelines. Hypertension. 2020;75(6):1334-57. https://doi.org/10.1161/ HYPERTENSIONAHA.120.15026

PMid:32370572

9. World Health Organization, International Diabetes Federation. Definition and Diagnosis of Diabetes Mellitus and Intermediate Hyperglycaemia: Report of a WHO/IDF Consultation. Geneva: World Health Organization; 2006. p. 1-50. Available from: http:// www.who.int/diabetes/publications/diagnosis_diabetes2006/en [Last accessed on 2021 Aug 19].

10. Fathurohman I, Fadhilah M. Description of risk level and factors related to risk of Type 2 diabetes mellitus in Buaran, Serpong. J Kedokteran Yarsi. 2016;24(3):186-202.

11. Trisnawati SK, Setyorogo S. Risk Factors for Type II diabetes mellitus in Cengkareng district Health Center, West Jakarta in 2012. J Ilmiah Kesehatan. 2013;5(1):6-11.

12. Mildawati, Diani N, Wahid A. Relationship between age, gender and duration of diabetes patients with the incidence of diabetic peripheral neuropathy. Carsing Nurs J. 2019;3(2):31-7.

13. Melmed S, Polonsky KS, Larsen PR, Kronenberg H. Williams Textbook of Endocrinology: Expert Consult. London: Elsevier Health Sciences; 2011.

14. Kaaja R. Diabetes in women: Pathophysiology and therapy. Obstet Med. 2011;4(2):86.

15. Kurniawaty E, Yanita B. Risk factors related Type 2 diabetes mellitus evidance. J Majority. 2016;5(2):27-31.

16. Smeltzer SC, Bare BG, Hinkle JL, Cheever KH. Brunner and Suddarth's Textbook of Medical Surgical Nursing. $12^{\text {th }}$ ed. Philadelphia, PA, Baltimore: Lippincott Williams and Wilkins; 2009. p. 2240.

17. Arisman MB. Obesitas, Diabetes Mellitus, dan Dislipidemia. Jakarta: EGC; 2013.

18. Toruan PL. Fat-Loss Not Weight-loss for Diabetes. Jakarta:
TransMedia; 2012.

19. Misnadiarly. Diabetes Mellitus: Gangren, Ulcer, Infeksi. Mengenal Gejala, Menanggulangi, dan Mencegah Komplikasi. Jakarta: Puskata Populer Obor; 2006.

20. Misnadiarly. Diabetes Mellitus: Gangrene, Ulcer, Infection. Recognizing Symptoms, Overcoming, and Preventing Complications. Jakarta: Puskata Populer Obor; 2006.

21. Javanbakht M, Abolhasani F, Mashayekhi A, Baradaran HR, Noudeh YJ. Health related quality of life in patients with Type 2 diabetes mellitus in Iran: A national survey. PLoS One. 2012;7(8):e44526. https://doi.org/10.1371/journal. pone.0044526 PMid:22952989

22. Kurniadi H. Stop! Diabetes Hipertensi Kolesterol Tinggi Jantung Koroner. Yogyakarta: Istana Media; 2015.

23. Dini CY, Sabila M, Habibie IY, Nugroho FA. Asupan Vitamin C dan E Tidak mempengaruhi kadar gula darah puasa pasien DM Tipe 2. Indones J Hum Nutr. 2018;4(2):65-78.

24. Lubis IK, Susilawati S. Analysis of Length of Stay (Los) Based on Predictor Factors in Type II DM Patients at PKU Muhammadiyah Hospital Yogyakarta. Jurnal Kesehatan Vokasional. 2018;2(2):161-6.

25. Wati $\mathrm{A}$. The relationship between dietary compliance compliance with blood glucose levels in diabetes mellitus patients. Bul Sariputra. 2015;5(1):40-6.

26. Nashrullah RF, Ari N, Wijaya SA, Adyani A. Relationship between Motivation and Type II diabetes mellitus dietary compliance. MAGNA MEDIKA. 2021;8(2):60-70.

27. Azis A, Aminah S. Motivation and diet compliance of Type II DM patients in the work area of the kendal kaliwungu health center. J Smart Keperawatan. 2018;5(1):72-9.

28. Rahmawati SD, Wahyuningsih AS, Yalestyarini EA. Diet compliance analysis towards blood sugar levels for diabetes mellitus patients. J Nurs Pract. 2018;2(1):73-9.

29. Beckman JA, Creager MA. Vascular complications of diabetes. Circ Res. 2016;118(11):1771-85. https://doi.org/10.1161/ CIRCRESAHA.115.306884 PMid:27230641

30. Trikkalinou A, Papazafiropoulou AK, Melidonis A. Type 2 diabetes and quality of life. World J Diabetes. 2017;8(4):120-9. https://doi.org/10.4239/wjd.v8.i4.120 PMid:28465788

31. Jensen ML, Jørgensen ME, Hansen EH, Aagaard L, Carstensen B. A multistate model and an algorithm for measuring long-term adherence to medication: A case of diabetes mellitus Type 2. Value Health. 2014;17(2):266-74. https://doi.org/10.1016/j.jval.2013.11.014 PMid:24636386

32. Ismansyah I, Ernawati R, Kusumastuti A. Factors associated with length of days of hospitalization for Type II diabetes miletus patients. J Husada Mahakam. 2012;3(4):154-62.

33. Sami W, Ansari T, Butt NS, Hamid MRA. Effect of diet on Type 2 diabetes mellitus: A review. Int J Health Sci (Qassim). 2017;11(2):65-71.

PMid:28539866 